\title{
Internal corporate social responsibility and organizational creativity: An empirical study of Vietnamese small and medium-sized enterprises
}

\author{
Ngoc Nhu Nguyen ${ }^{1,2}(\mathbb{D})$, Tuan Phong Nham ${ }^{3 *}(\mathbb{D})$, Yoshi Takahashi ${ }^{1}$ \\ ${ }^{1}$ Graduate School for International Development and Cooperation, Higashi Hiroshima (Japan), \\ ${ }^{2}$ Ton Duc Thang University, Ho Chi Minh City (Vietnam) \\ ${ }^{3}$ VNU University of Economics and Business, Hanoi City (Vietnam) \\ nguyennbungoc@tdtu.edu.vn,*corresponding author:tuannp@vnu.edu.vn,yosbi@@birosbima-u.ac.jp
}

Received October, 2018

Accepted December, 2019

\begin{abstract}
Purpose: The present study investigates the relationship between internal corporate social responsibility (CSR), a type of CSR particularly for employees within organizations, and organizational creativity. The focus is on the mediating effects of affective commitment and knowledge sharing within the relationship.
\end{abstract}

Design/methodology: Data were collected in Vietnam via questionnaire survey. Regarding survey administration, first, we chose the five biggest universities, which specialized in economics and business in Hanoi. Then, from those universities, we randomly selected graduate classes whose students are fulltime employees in various companies around Hanoi. The questionnaire included 5 point Likert scale multi-items designed to measure factors. Among 750 distributed questionnaires, 252 were returned. After screening and deleting those questionnaires with missing information or those from large companies, 199 remained for further investigation, representing $26.53 \%$ of the valid response rate. The sample included 117 manufacturing and 82 non-manufacturing companies. For the statistical analysis of the data, we followed the three-step procedure of exploratory factor analysis (EFA), confirmatory factor analysis (CFA), and structural equation modeling.

Findings: Results support our hypotheses that predict positive mediating effects, except for the direct relationship between training and development as one aspect of internal CSR and affective commitment, although training and development have an indirect relationship with organizational creativity through knowledge sharing.

Originality/value: The study contributes to the literature on internal CSR, especially because it provides the valid empirical evidence for the relationship between internal CSR and organizational creativity, which needs more clarification regarding the process. We emphasize the importance of findings to the case of small and medium-sized enterprises in developing countries, because they often face difficulties implementing external CSR due to resource constraints.

Keywords: Affective commitment, Internal CSR, Knowledge sharing, Organizational creativity, Small and medium-sized enterprises, Vietnam 
Jel Codes: M12, M 14

\section{To cite this article:}

Nguyen, N.N., Nham, T.P., \& Takahashi, Y. (2019). Internal corporate social responsibility and organizational creativity: An empirical study of Vietnamese small and medium-sized enterprises. Intangible Capital, 15(3), 208-223. https://doi.org/10.3926/ic.1382

\section{Introduction}

Corporate social responsibility (CSR) has recently considered a predictor of business performance and an opportunity to achieve sustainable development in business and the wider environment. However, substantial change within CSR implementation and management has been witnessed to adapt to a new and rapidly changing global business environment. Alongside this progress, the idea that companies should change from discretionary CSR activities to some strategically chosen CSR activities, for example, internal CSR has received more attention from both researchers and practitioners. Tang, Hull and Rothenberg's (2012) empirical study finds that firms benefit more when they start CSR with internal aspects rather than external ones. Supporters of internal CSR believe that it provides value for organizations because it is a determinant of employees' dedication, commitment, motivation, engagement, and loyalty all of which have shown a positive correlation with firm performance (Cooke \& He, 2010; Farrukh, Sajid, Lee \& Shahzad, 2019; Lee \& Chen, 2018). Despite the importance of internal CSR, very few published works explicitly show the mechanism how it is beneficial to organizations, especially in the case of small and medium-sized enterprises (SMEs). It seems easier and more effective for SMEs with limited budgets and time constraints to implement internal CSR, whose main aims are to create a good working environment and to help employees develop. This idea is supported in the argument of Jamali, El Dirani and Harwood (2015) that external CSR is easier for competitors to imitate while internal CSR becomes tacit and a source of organizational development.

Among potential outcomes from internal CSR, organizational creativity (which includes employee creativity and creative working environment) has been considered to impact positively on firm performance, and this relationship has been heavily evidenced (Bharadwaj \& Menon, 2000; Lee, Gon Kim \& Kim, 2012; Liu, Gong, Zhou \& Huang, 2017; Zhang \& Begley, 2011). Laursen and Foss (2003) and Shipton, West, Dawson, Birdi and Patterson (2006) argue that to ensure creativity and innovation processes achieve results, not only research and development professionals but also other employees should be involved, which may require more internal CSR practices. In addition, firms need to create a suitable context to enhance individuals' motivation and commitment to learning and sharing knowledge for creativity application purposes (Chuang, Jackson \& Jiang, 2016; Collins \& Smith, 2006). Indeed, in order for organizations to enjoy benefits from creativity and innovation, employees' creativity levels are not sufficient, but rather, the organizational level of creativity as creative working environment where ideas flow may be more important (Bharadwaj \& Menon, 2000; Çekmecelioğlu \& Günsel 2013). From these arguments, internal CSR seems to be a potential determinant of organizational creativity, since it can stimulate affective commitment and encourage knowledge sharing among employees inside the organization (Mory, Wirtz \& Göttel, 2016). Nevertheless, the specific mechanism of how internal CSR leads to organizational creativity is still unanswered. Therefore, more research is needed to address the issue, particularly from the perspective of SMEs. The present research attempts to fill the research gap by providing empirical evidence for the relationship between internal CSR and organizational creativity with the effects of potential mediators, namely affective commitment and knowledge sharing activities among employees in the SME environment. 


\section{Literature review and hypothesis development}

\subsection{Internal corporate social responsibility}

There are many definitions of CSR as well as different perspectives on how CSR should be introduced and implemented in organizations. According to stakeholder theory, CSR is essentially divided into two categories: external and internal CSR. External CSR includes three main issues, namely, corporate philanthropy, corporate volunteerism, and environmental protection (European Commission, 2001), while the core of internal CSR involves the employees and employment relationship. Spence and Lozano (2000) claimed that the strongest incentive for SMEs to undertake CSR is concern for employees' health and welfare, and thus, SMEs are more likely to start CSR with internal aspects. Previous researchers have argued that general CSR and HRM could not be the same, but they are becoming increasingly overlapped, especially in terms of internal CSR (Bettridge, 2007; Cooke \& He, 2010). CSR and HRM sometimes share common goals and a common concern for responsible employment practices (Ehnert \& Harry, 2011; Fenwick \& Bierema, 2008). Nevertheless, to implement internal CSR, traditional HRM is required to have more capabilities and to integrate extra aspects (Inyang, Awa \& Enuoh, 2011; Jamali et al., 2015). In other words, internal CSR may be considered responsible aspects of HRM. As a result, internal CSR somehow functions as fundamental HRM activities, and is considered an effective strategy to encourage personnel satisfaction, employee affective commitment and engagement, and knowledge sharing activities (Chaudhary \& Akhouri, 2018; Gupta \& Sharma, 2016; Story \& Neves, 2015) and in turn, boost organizational creativity (Chaudhary \& Akhouri, 2018; Hur, Moon \& Ko, 2018). Researchers may provide different descriptions when mentioning internal CSR, but they share key issues regarding human rights, physical and psychological working conditions, employment relationship, and human development (European Commission, 2001; Murillo \& Lozano, 2006; Turker, 2009). This idea is found in previous work when researchers have attempted to develop different scales to measure internal CSR, such as Maignan and Ferrell (2004), Papasolomou-Doukakis, Krambia-Kapardis and Katsioloudes (2005), Turker (2009) and Welford (2005). This study focuses on four aspects of internal CSR: work diversity, human rights, training and development, and work- life balance.

\subsection{Organizational creativity}

Creativity in the workplace is defined as "the production of novel and useful ideas" (Amabile, 1988, p. 126). Additionally, creativity at the organization level may be also referred as a creative and collaborative working climate (Zhang \& Begley, 2011; Sundgren, Dimenäs, Gustafsson \& Selart, 2005). An organization may need both individual creativity and organizational creative climate which enables employees' ideas to become measurably innovative outputs (Bharadwaj \& Menon, 2000; Sarooghi, Libaers \& Burkemper, 2015). For measurement in empirical studies, researchers often use proxy variables, such as personality characteristics for the individual level and organizational structure and working environment for the organizational level of creativity. Note that personality characteristics have also been used as measures of organizational creativity, because individual creativity is regarded as one aspect of organizational creativity. According to Amabile, Conti, Coon, Lazenby and Herron (1996), personality characteristics and organizational structures have dominated the organizational creativity literature. However, from management perspectives, the working environment may be more useful, because both personality characteristics and organizational structures are harder to intervene in than the working environment. Furthermore, the authors claim that perceived work environment makes a difference in the level of creativity in organizations, which is in line with the findings of the empirical study of Imran, Saeed, Anis-Ul-Haq and Fatima (2010). Thus, this study focuses on organizational creativity as a creative working environment.

\subsection{Relationship between internal CSR, affective commitment, and organizational creativity}

With the focus on employees, internal CSR, a feasible option for SMEs, may also be a possible determinant of organizational creativity, since it may promote an open and more creative working environment through selected CSR activities, such as diversity promotion, training programs, creation of work-life balance, and family friendly employment (Jenkins, 2009; Mendibil, Hernandez, Espinach, Garriga \& Macgregor, 2007). As mentioned in the introduction, internal CSR may have positive effect on organizational creativity via affective commitment. 
Broadly defined, organizational commitment refers to the psychological state that characterizes the relationship between employees and organization, and has implications for the decision to continue or discontinue membership in that organization (Miller \& Lee, 2001; Meyer, Stanley, Herscovitch \& Topolnytsky, 2002). Among three kinds of organizational commitment-namely, affective commitment, normative commitment, and continuance commitment-affective commitment seems to be the most beneficial for organizations as it can activate employees' love and desire to contribute to the organizations (Allen \& Meyer, 1990; Miller \& Lee, 2001; Meyer et al., 2002).

Internal CSR has been considered as a source of affective commitment when prior studies have claimed a positive relationship between those two (Al-bdour, Nasruddin \& Lin, 2010; Rettab, Brik \& Mellahi, 2009; Thang \& Fassin, 2017). The focus of internal CSR is on employees, and it aims to help employees have a good working environment and develop more opportunities. Affective event theory (Weiss \& Cropanzano, 1996) implies that employees who work for a company with better internal CSR practices are more likely to display positive contribution to their organization's development, as it seems to be a natural reaction of employees when they have feelings of want, love, and commitment to company goals. Accordingly, human practices or internal CSR in this case influences affective states of employees through work context and events. The better one organization is perceived by employees, the more employees feel attached and want to contribute to its success (Al-bdour et al., 2010; Rettab et al., 2009; Thang \& Fassin, 2017). As a result, employees are motivated to find better solutions for their jobs and to promote creativity within the organization. In line with this argument, Jafri (2010) and McLean (2005) claim that affective commitment is very important in the creative ability development of employees.

Furthermore, when employees have high affective commitment, their intrinsic motivation is triggered, which may result in more searching, self-learning activities, and risk taking, ultimately leading to more creativity for organizations (Bodla \& Naeem, 2014; de Jesus, Rus, Lens \& Imaginário, 2013; Hur et al, 2018; Zhang \& Bartol, 2010). Especially, in relation to our focus on the work environment aspect of organizational creativity, employees are considered to have more intention to share their daily lives with colleagues because they may feel more trust and friendliness to do so. Those activities enhance internal communication, even without knowledge sharing, which might result in a flexible and collaborative working environment for creative development. It is supposed to be helpful since organizational creativity in this research focuses more on the creative working environment. From this basis, we believe that organizations with employees who have strong affective commitment enjoy more creativity than organizations with employees who have weak affective commitment. Summarizing the discussion, affective commitment is a potential mediator in the internal CSR practices and organizational creativity relationship.

Nevertheless, whether affective commitment plays a role of a full or partial mediator is unclear in the literature. The reason is because on one hand, internal CSR practices also include providing employees training and education, which may directly bring new ideas, discussions, and debates via training sessions, which fosters organizational creative environment. On the other hand, it is noteworthy that without motivation such as affective commitment and the specific actions such as knowledge sharing or debates, impact of training and education on organization may not be significant. Therefore, we hypothesize:

\section{H1: Affective commitment mediates the positive relationship between internal CSR and organizational creativity.}

\subsection{Relationship between internal CSR, knowledge sharing, and organizational creativity}

Knowledge sharing is known as "a process that enables the knowledge of individuals and groups to be transferred to the organizational level, where it can be applied for the development of new products, services, and processes" (Camelo-Ordaz, Garcia-Cruz, Sousa-Ginel \& Valle-Cabrera, 2011, p. 1442). Since the knowledgebased economy has rapidly become dominant, knowledge sharing has become more and more essential for organizations. Previous empirical studies show a positive relationship between HRM and knowledge sharing within organizations (Fong, Ooi, Tan, Lee \& Yee-Loong Chong, 2011; Chiang, Han \& Chuang, 2011). As argued, internal CSR is a kind of responsible HRM, and thus, empirical studies that advocate positive impacts of HRM 
on knowledge sharing may be applied to internal CSR as well. The policies from programs of diversity promotion or intervention to other kinds of employee motivation (e.g., extrinsic motivation) by compensation and reward systems will help to enhance knowledge-sharing activities (Shen, Tang \& D'Netto, 2014). Hence, once a company implements internal CSR that enhances active communication and diversity among employees, knowledge-sharing activities are supposed to occur more often.

The importance of knowledge sharing for creativity in organizations has been highlighted in previous studies (Carmeli, Gelbard \& Reiter-Palmon, 2013; Hu, Horng \& Sun, 2009; Zhang \& Begley, 2011). Knowledge sharing is an essential process in converting individual learning to organizational competences, including the creativity of employees. Various kinds of knowledge from different people, disciplines, and expertise provide valuable inputs for the organizational creative climate, especially if ideas can be discussed freely and flow. As Amabile et al. (1996) claim, a favorable working environment for employees to create is one of the biggest factors in fostering organizational creativity, because it allows disconnected ideas, views, facts, perspectives, experiences, expertise, and information to be connected, shared openly, and argued. From above rationale, knowledge sharing may mediate the internal CSR-organizational creativity path. Nevertheless, similar to affective commitment, the question of whether knowledge sharing fully or partially mediates the relationship needs more investigation. Therefore, we hypothesize the general mediation as follows:

\section{H2: Knowledge sharing mediates the positive relationship between internal CSR and organizational creativity.}

\subsection{Affective commitment and knowledge sharing}

Knowledge is valuable asset for both individuals and organizations. If knowledge is widely shared and deliberated, it brings many benefits to an organization. However, Hislop (2003) states in his research that knowledge sharing is an activity that requires voluntary effort because it goes beyond employees' contractual obligations. Employees may perceive knowledge as their own assets and competences; thus, it would be a loss if their own knowledge were shared with other people. People are reluctant to share their information and knowledge, since sharing could be very risky to them when someone else might utilize that information against them. This issue corresponds to the social dilemma of knowledge sharing that says people hesitate to share knowledge because they perceive that activity as decreasing their influence and making others' contribution increased (Lam \& Lambermont-Ford, 2010). Another reason causing employees to share their knowledge less is fear of losing face, which is found more readily in collectivism countries, like China and Vietnam. Employees who communicate knowledge may feel ashamed if it lacks value to recipients. When asking for help, they are afraid of being thought less knowledgeable by other people (De Luque \& Sommer, 2000; Hwang, Francesco \& Kessler, 2003). Consequently, affective commitment is emerging as a critical factor that helps people to overcome their natural resistance to knowledge sharing (Allen \& Meyer, 1996; Hislop, 2003). Employees with strong affective commitment become more involved in a company's common affairs that are not their official duties. Affective commitment seems to be a strong driving force leading employees to voluntary knowledge-sharing behavior. This argument is supported in the empirical studies of Camelo-Ordaz et al. (2011) and Van den Hooff and De Ridder (2004). Thus, we propose the following hypothesis.

\section{H3: Affective commitment and knowledge sharing are positively related.}

\section{Methodology}

\subsection{Sample and data collection}

This study is at the firm level, and data were collected in Vietnam via questionnaire survey. Regarding survey administration, first, we chose the five biggest universities, which specialize in economics and business in Hanoi. Then, from those universities, we randomly selected weekend graduate classes whose students are full-time employees in various companies around Hanoi. Of 25 classes, 13 were contacted randomly. We asked for their support to take the questionnaire to their direct bosses to answer, as our target respondents are departmental managers and executive managers. The signatures of the direct bosses and confirmation from the companies are required. Among 750 distributed questionnaires, 252 were returned in sealed envelopes provided by the 
researchers. After screening and deleting those questionnaires with missing information or those from large companies, 199 remained for further investigation, representing $26.53 \%$ of the valid response rate. There are 117 manufacturing companies and 82 non-manufacturing companies in this sample. Concerning firm size, $14.6 \%$ have no more than 10 employees, $63.7 \%$ have $11-200$ employees, and $21.7 \%$ have $201-300$ employees. In terms of firm ownership, companies in the sample fall into four main types: $30.0 \%$ are stated-owned enterprises, $17.1 \%$ are joint venture firms, $24.5 \%$ are private firms, and $28.4 \%$ are limited joint stock firms. The average firm age is around 10 years. Moreover, respondents come from various departments, such as sales and marketing, production, human resources, procurement, administration, accounting and finance, technical, quality control, and executive board of directors.

\subsection{Treatment of common method variance}

The Harman one-factor test is used to examine the potential problem of common method variance. The results produce seven factors with eigenvalues greater than one, which account for $62.74 \%$ of the total variance, and the first factor accounts for only $18.42 \%$ of the total variance. Therefore, the problem of common method variance does not exist significantly in this study.

\subsection{Non-response bias check}

The procedures recommended by Rogelberg and Stanton (2007) are used to check the possibility of nonresponse bias. Specifically, we compare early and late responses when questionnaires are returned based on the assumption that late respondents can be representative of theoretical non-respondents. We test mean differences of all multiple item scales. No significant difference is detected ( $p>0.05)$, indicating that non-response bias is not a serious issue in this study.

\subsection{Measurements}

A five-point Likert scale is used to capture information from respondents, ranging from $1=$ strongly disagree to $5=$ strongly agree. All 16 items used to measure internal CSR are adapted from previous researchers. In this study, internal CSR includes four main aspects, namely, work diversity, human rights, training and development, and work-life balance. Regarding work diversity, we use three items adapted from Magoshi and Chang (2009) for our measurement. The human rights measurement uses three indicators, which are adopted from Al-bdour et al. (2010). With regard to training and development, six items are adopted from Lee and Bruvold (2003). There are four items in the measurement of work-life balance, which are adapted from Smith and Gardner (2007). We use five indicators adopting from Cummings (2004) to obtain information about how employees often share their knowledge with other people within their companies, as perceived by managers. A five-point Likert scale is used, ranging from $1=$ never to $5=$ a lot. A measurement developed by Allen and Meyer (1990) is used in this study to measure affective commitment. Respondents are asked to evaluate the affective commitment levels of employees in their organization in general. A five-point Likert scale is used to capture the level of their agreement with designated descriptions ranging from $1=$ strongly disagree to $5=$ strongly agree. Finally, 11 items were adopted from Amabile and Gryskiewicz (1989) to measure organizational creativity. Respondents are asked to give their opinions on the level of organizational creativity by choosing options from $1=$ strongly disagree to $5=$ strongly agree. We control the most common aspects, namely, firm size, firm age, firm ownership, and industry (Kotha, Zheng \& George, 2011; Sarooghi et al., 2015; Von Nordenflycht, 2007). Stateowned enterprises were coded 1 and 0 otherwise. Similarly, we coded 1 for manufacturing firms and 0 for nonmanufacturing firms to control the difference.

Below is the conceptual framework for the current research. 


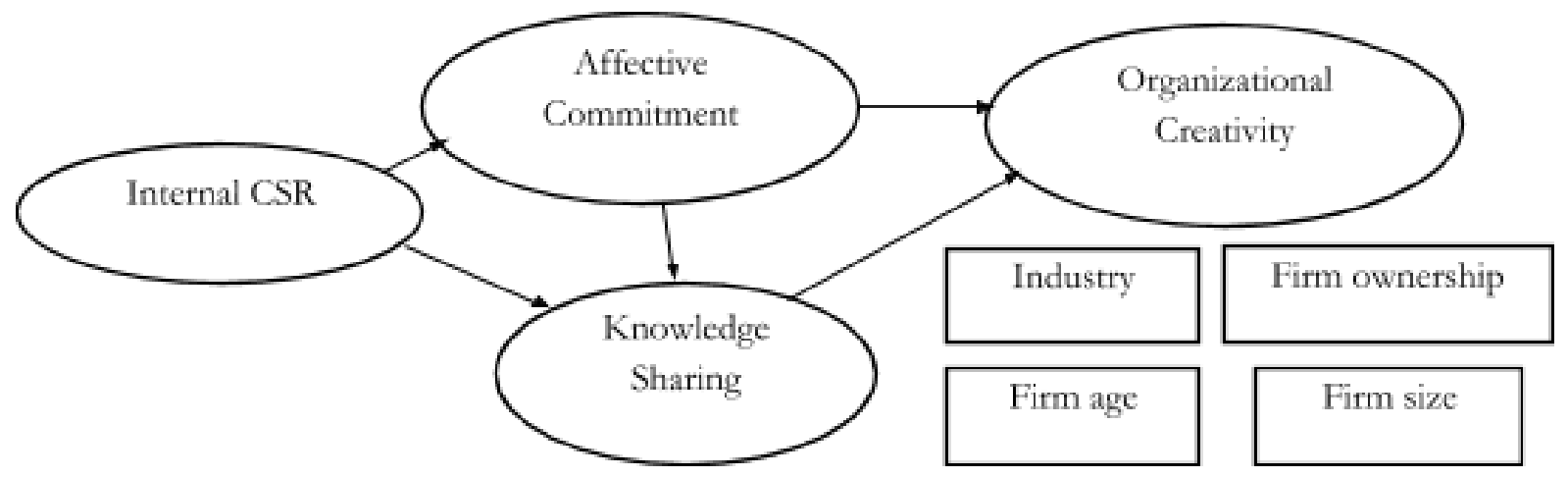

Figure 1. Conceptual framework

\section{Data analysis and results}

For the statistical analysis of the data, we follow the three-step procedure of exploratory factor analysis (EFA), confirmatory factor analysis (CFA), and structural equation modeling using SPSS and AMOS software, version 23. The means, standard deviations, and correlations among all latent variables are shown in Table 1.

Moreover, prior to hypothesis testing, we check the reliability and validity of the measurement model. First, all the manifest variables are put into EFA separately by expected latent factors to check their reliability. All Cronbach's $\alpha$ scores are greater than 0.7 and factor loadings are greater than 0.5. However, according to Thurstone (1947), items that run under more than two factors without the difference of at least 0.15 should be deleted. One item of human rights and all the indicators of work-life balance are deleted for that reason. After ensuring all sufficient requirements for each latent variable by individual EFA checking, we put all latent variables into one EFA to check whether any combine. Three items of the work diversity factor and two items of the human rights factor show integration together. After judging the content of these results, we rename them as one factor, so-called 'workplace practices'. The EFA results are shown in Table 2. The hypotheses are modified for greater clarity as follows.

H1: Internal CSR and organizational creativity are positively related, mediated by affective commitment of employees.

H1.1: Workplace practices and organizational creativity are positively related, mediated by affective commitment of employees.

H1.2 The training and development practices and organizational creativity are positively related, mediated by affective commitment of employees.

H2: Internal CSR and organizational creativity are positively related, mediated by knowledge sharing activities of employees.

H2.1: Workplace practices and organizational creativity are positively related, mediated by knowledge sharing activities of employees.

H2.2: Training and development practices and organizational creativity are positively related, mediated by knowledge sharing activities of employees.

H3: Affective commitment and knowledge sharing are positively related. 


\begin{tabular}{|c|c|c|c|c|c|c|c|c|c|c|}
\hline & Mean & $\begin{array}{l}\text { Standard } \\
\text { Deviation }\end{array}$ & 1 & 2 & 3 & 4 & 5 & 6 & 7 & 8 \\
\hline $\begin{array}{l}\text { 1. Workplace } \\
\text { Practice }\end{array}$ & 3.49 & 0.69 & 1 & & & & & & & \\
\hline $\begin{array}{l}\text { 2. Training and } \\
\text { Development }\end{array}$ & 3.56 & 0.63 & -.091 & 1 & & & & & & \\
\hline $\begin{array}{l}\text { 3. Affective } \\
\text { Commitment }\end{array}$ & 3.56 & 0.61 & $.401^{* *}$ & -.100 & 1 & & & & & \\
\hline $\begin{array}{l}\text { 4. Knowledge } \\
\text { Sharing }\end{array}$ & 3.57 & 0.63 & $.338^{* *}$ & .098 & $.393^{* *}$ & 1 & & & & \\
\hline $\begin{array}{l}\text { 5. Organizational } \\
\text { Creativity }\end{array}$ & 3.64 & 0.59 & $.168^{* *}$ & -.090 & $.438^{*}$ & $.383^{* *}$ & 1 & & & \\
\hline 6. Firm Age & 10.18 & 8.86 & .088 & .047 & -.067 & -.066 & -.106 & 1 & & \\
\hline 7. Ownership & 0.42 & 0.50 & $-.134^{*}$ & -.039 & $-.162^{*}$ & $-.181^{* *}$ & $-.343^{* *}$ & .024 & 1 & \\
\hline 8. Industry & 0.60 & 0.49 & -.083 & .018 & -.067 & -.006 & $.214^{* *}$ & .059 & $-.616^{* *}$ & 1 \\
\hline
\end{tabular}

*: Significant at $0.1, * *$ : Significant at 0.05

Firm size was not calculated as the obtained information revealed the range of the number of employees only

Table 1. Mean, standard deviation, and correlations

\begin{tabular}{|c|c|c|c|}
\hline Factors & Items & $\begin{array}{l}\text { Factor } \\
\text { loading }\end{array}$ & Cronbach's $\alpha$ \\
\hline \multirow{5}{*}{ Workplace Practices } & $\begin{array}{l}\text { Our company conducts diversity training programs } \\
\text { with compulsory participation for all employees }\end{array}$ & 0.84 & \multirow{5}{*}{0.91} \\
\hline & $\begin{array}{l}\text { Our company provides equal opportunities to all } \\
\text { employees about pays, bonus, and growth } \\
\text { opportunities }\end{array}$ & 0.82 & \\
\hline & $\begin{array}{l}\text { Our company conducts equal recruitment no matter } \\
\text { which sex, religion or ethnic }\end{array}$ & 0.80 & \\
\hline & $\begin{array}{l}\text { Our company offers training programs to help women } \\
\text { employees to develop their leadership skills }\end{array}$ & 0.83 & \\
\hline & $\begin{array}{l}\text { Employees are allowed to give his/her opinion to } \\
\text { contribute to the development of our company }\end{array}$ & 0.85 & \\
\hline \multirow{6}{*}{$\begin{array}{l}\text { Training and } \\
\text { Development Practices }\end{array}$} & $\begin{array}{l}\text { Our company trains employees on skills that prepare } \\
\text { them for future jobs and career development }\end{array}$ & 0.78 & \multirow{6}{*}{0.87} \\
\hline & $\begin{array}{l}\text { Our company provides consulting and supportive } \\
\text { activities for employees on their future job and career } \\
\text { development }\end{array}$ & 0.80 & \\
\hline & $\begin{array}{l}\text { Our company allows employees to have time to learn } \\
\text { new skills that prepare them for future job }\end{array}$ & 0.79 & \\
\hline & $\begin{array}{l}\text { Our company is receptive to employees' request to } \\
\text { lateral transfers (transfer to another department) }\end{array}$ & 0.79 & \\
\hline & $\begin{array}{l}\text { Our company provides employees with information } \\
\text { on the availability of job openings inside the company }\end{array}$ & 0.80 & \\
\hline & $\begin{array}{l}\text { Our company supports employees when they decide } \\
\text { to obtain ongoing training }\end{array}$ & 0.70 & \\
\hline \multirow{6}{*}{ Knowledge Sharing } & \multicolumn{2}{|l|}{$\begin{array}{l}\text { On average, how often did your employees share each type of } \\
\text { knowledge with others in your company? }\end{array}$} & \multirow{6}{*}{0.87} \\
\hline & $\begin{array}{l}\text { General overviews (e.g., department goals, milestone } \\
\text { estimates, or member responsibilities) }\end{array}$ & 0.80 & \\
\hline & $\begin{array}{l}\text { Specific requirements (e.g., forecasts, order requests or } \\
\text { characteristics of products/services/customers) }\end{array}$ & 0.79 & \\
\hline & $\begin{array}{l}\text { Analytical techniques (e.g., statistical tools, detailed } \\
\text { methods, testing procedures or specific indicators of } \\
\text { measurement) }\end{array}$ & 0.65 & \\
\hline & $\begin{array}{l}\text { Progress reports (e.g., status updates, resource } \\
\text { problems, or personnel evaluations) }\end{array}$ & 0.74 & \\
\hline & $\begin{array}{l}\text { Results (e.g., preliminary findings, unexpected } \\
\text { outcomes, existed difficulties, or clear } \\
\text { recommendations) }\end{array}$ & 0.82 & \\
\hline
\end{tabular}




\begin{tabular}{|c|c|c|c|}
\hline Factors & Items & $\begin{array}{l}\text { Factor } \\
\text { loading }\end{array}$ & Cronbach's $\alpha$ \\
\hline \multirow{7}{*}{ Affective Commitment } & $\begin{array}{l}\text { Our employees would be very happy to spend the rest } \\
\text { of their career with our company }\end{array}$ & 0.51 & \multirow{7}{*}{0.89} \\
\hline & $\begin{array}{l}\text { Our employees enjoy talking about our company with } \\
\text { people outside it }\end{array}$ & 0.80 & \\
\hline & $\begin{array}{l}\text { Our employees really feel as if this company's } \\
\text { problems are their own }\end{array}$ & 0.73 & \\
\hline & $\begin{array}{l}\text { This company has a great deal of personal meaning } \\
\text { for me }\end{array}$ & 0.72 & \\
\hline & $\begin{array}{l}\text { Our employees do not feel like "part of the family" at } \\
\text { our company }\end{array}$ & 0.83 & \\
\hline & $\begin{array}{l}\text { Our employees do not feel "emotionally attached" to } \\
\text { this company }\end{array}$ & 0.78 & \\
\hline & $\begin{array}{l}\text { Our employees do not feel a strong sense of } \\
\text { belonging to our company }\end{array}$ & 0.60 & \\
\hline \multirow{11}{*}{$\begin{array}{l}\text { Organizational } \\
\text { Creativity }\end{array}$} & $\begin{array}{l}\text { Each person understands his/her role in, and his/her } \\
\text { contribution to the company }\end{array}$ & 0.72 & \multirow{11}{*}{0.92} \\
\hline & $\begin{array}{l}\text { People in the company can bring up new ideas and } \\
\text { opinions without quickly being criticized }\end{array}$ & 0.77 & \\
\hline & $\begin{array}{l}\text { The company allows employees to solve problems and } \\
\text { take actions that employees think are most suitable in } \\
\text { a given situation }\end{array}$ & 0.69 & \\
\hline & The company has a dynamic atmosphere & 0.74 & \\
\hline & $\begin{array}{l}\text { There is a free atmosphere in the organization, where } \\
\text { the seriousness of the task can be mixed with unusual } \\
\text { ideas and humor }\end{array}$ & 0.73 & \\
\hline & $\begin{array}{l}\text { Different opinions, ideas, experience, and knowledge } \\
\text { can be discussed freely in the company }\end{array}$ & 0.74 & \\
\hline & $\begin{array}{l}\text { It is obvious that creativity is at the heart of this } \\
\text { company }\end{array}$ & 0.68 & \\
\hline & The company has a stimulating atmosphere & 0.70 & \\
\hline & The company enthusiastically welcomes new ideas & 0.76 & \\
\hline & $\begin{array}{l}\text { The climate and environment in the company is } \\
\text { basically positive and encourages new ideas }\end{array}$ & 0.78 & \\
\hline & $\begin{array}{l}\text { There is an easy, natural flow of ideas within the } \\
\text { company }\end{array}$ & 0.60 & \\
\hline
\end{tabular}

\section{Kaiser-Mayer-OlkinIndex $=0.88$}

Table 2. Exploratory factor analysis (the 2nd time)

Then, we use the pattern matrix from EFA to build a CFA measurement model in AMOS. The critical ratio (CR), which is greater than 0.7 in all cases, confirms the composite validity of the scales. The convergent validity is achieved because no average variance extracted (AVE) is less than 0.5. Finally, discriminant validity is confirmed when all AVE are greater than the maximum shared variance (MSV). The results are shown in Table 3.

\begin{tabular}{|c|c|c|c|c|c|c|c|c|c|}
\hline Variables & CR & AVE & MSV & ASV & 1 & 2 & 3 & 4 & 5 \\
\hline 1. Workplace practices & 0.91 & 0.67 & 0.22 & 0.10 & 0.82 & & & & \\
\hline 2. Training and Development & 0.87 & 0.54 & 0.01 & 0.01 & -0.12 & 0.73 & & & \\
\hline 3. Knowledge Sharing & 0.87 & 0.57 & 0.22 & 0.14 & 0.38 & 0.10 & 0.76 & & \\
\hline 4. Affective Commitment & 0.90 & 0.55 & 0.22 & 0.17 & 0.47 & -0.09 & 0.47 & 0.74 & \\
\hline 5. Organizational Creativity & 0.92 & 0.51 & 0.22 & 0.11 & 0.18 & -0.10 & 0.41 & 0.47 & 0.71 \\
\hline
\end{tabular}

Table 3. Validity checking

We checked the model fitness for the measurement model. Accordingly, degree of freedom is 505 , chi-square is 674.54, $\mathrm{CMIN} / \mathrm{df}=1.34, \mathrm{CFI}=0.953, \mathrm{TLI}=0.948, \mathrm{IFI}=0.954, \mathrm{GFI}=0.85$; $\mathrm{SRMR}=0.058, \mathrm{RMSEA}=$ 0.041 , and P-close $=0.97$, which represent a close model fit, according to Hu and Bentler (1998). When it is certain that our data are reliable and valid, we continue with the structural equation modeling to check the 
hypotheses. The model fitness of the structural model is also satisfactory. Degree of freedom is 640, chi-square is $846.57, \mathrm{CMIN} / \mathrm{df}=1.32, \mathrm{CFI}=0.95, \mathrm{TLI}=0.94, \mathrm{IFI}=0.95, \mathrm{GFI}=0.83, \mathrm{SRMR}=0.067, \mathrm{RMSEA}=0.040$, and P-close is 0.98. All the numbers present a good fit for the model (Hu \& Bentler 1998).

In terms of our hypotheses, findings showed that knowledge sharing mediated the correlations between both aspects of internal CSR, namely workplace practices and training and development practices and organizational creativity, whereas affective commitment only mediated the association between workplace practices and organizational creativity. More specifically, two direct paths from both aspects of internal CSR to organizational creativity were not significant. Estimated coefficients were $-0.15,-0.12$ with $95 \%$ confidence intervals (CIs): [$0.33,0.04],[-0.26,0.02]$, and p-values $=0.14$ and 0.09 , for workplace practices and training and development, respectively. Coefficients for direct paths from workplace practices and training and development to knowledge sharing were $0.20,0.17$ with $95 \%$ CIs: $[0.02,0.36],[0.02,0.31]$, with p-values $=0.03$ and 0.02 , correspondingly. The association between knowledge sharing and organizational creativity was also significant with a coefficient of $0.26,95 \%$ CI: $[0.08,0.45], \mathrm{p}=0.004$. Combing these results, knowledge sharing fully mediated the associations between internal CSR and organizational creativity. Affective commitment showed its full mediation in the relation between workplace practices and organizational creativity, however it did not mediate the association between training and development practices and organizational creativity due to the insignificant path from training and development to affective commitment $(p=0.41)$. Workplace practices-affective commitment path had a coefficient of $0.47,95 \% \mathrm{CI}:[0.28,0.62]$, and $\mathrm{p}=0.002$. Affective commitment-organizational creativity path had a coefficient of $0.38,95 \% \mathrm{CI}$ : $[0.21,0.56]$, and $\mathrm{p}=0.001$. Finally, affective commitment and knowledge sharing are positively related with a coefficient of $0.40,95 \% \mathrm{CI}$ : [0.25, 0.55], and p $=0.001$. Results are also illustrated in Figure 2.

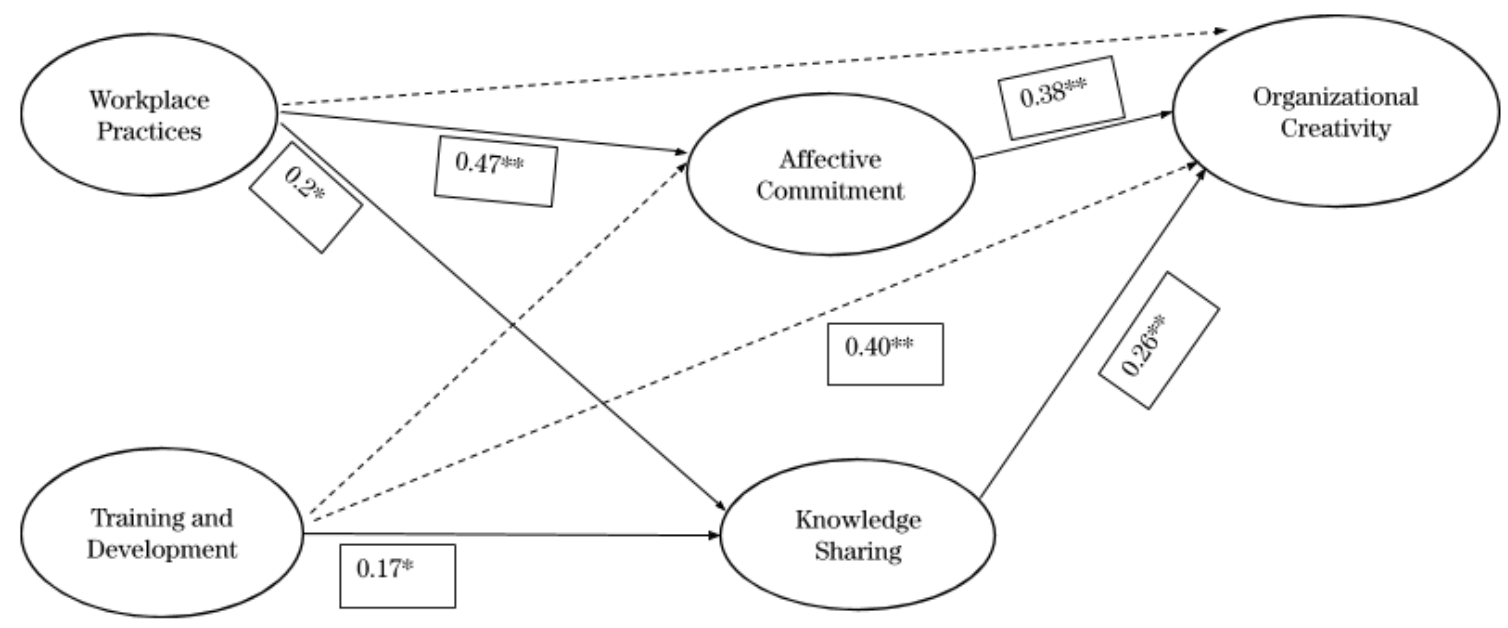

Figure 2. The results from structural equation modelling

\section{Discussion}

The study identified the mechanism how internal CSR leads to organizational creativity by incorporating potential mediating variables, namely affective commitment and knowledge sharing. As proposed, findings showed a mediating role of knowledge sharing in the relationship between internal CSR and organizational creativity. Similarly, being consistent with results from prior research, affective commitment also mediated the workplace practices and organizational creativity association. Nevertheless, a positive correlation between training and development activities of firms and employees' affective commitment was not supported. One possible reason could be the different perceptions of employees about the value and usefulness of training and development programs that they receive. There may be individuals who may not perceive such programs as valuable, and thus, the program has no significant effect on their decisions to be affectively committed to their companies or not. Another noteworthy aspect may be the difference among employees in terms of their moral identities, which could orient them to react differently to the same thing (Blasi, 1984, 1995). For example, all 
employees of one company receive the same training and development program, but people with strong moral identity feel thankful and greatly indebted to the company, thus they may feel love for the company and want to contribute more to its success. On the other hand, people with weak moral identity find such opportunities invaluable to them or even troublesome if training and education are perceived as unnecessary extra duties.

The difference between the effects of workplace and training and development on affective commitment may lie in the difference of portability between the two variables. Knowledge and skills acquired from training are easier for employees to take with them when they move to another company while the results of workplace practices seem to turn the working environment of the firm into its property. Moreover, from the findings, affective commitment showed its important role in the process from internal CSR to organizational creativity. The key inputs for organizational creativity are its people and the environment that enable organizations to ensure individuals' new ideas are shared and put into practice. Affective commitment can be one source not only motivating employees to create new ideas but also making the perceived climate more favorable for creativity. Thus, managers should start caring more about their employees' psychological welfare and attachment to the organization.

\section{Conclusion and limitations}

This study successfully tests the empirical relationship between internal CSR and organizational creativity by incorporating the mediating effects of affective commitment and knowledge sharing. Nevertheless, the study has several limitations. This work examines the average effect from companies in our sample, and thus the results may change owing to specific conditions of a particular company. Moreover, there may be some bias from the way in which we chose respondents. For example, affective commitment was measured by the perceptions of managers. This should in fact be measured by employees themselves. Furthermore, internal CSR and organizational creativity were measured by the evaluation of managers, who had different specialties. Even though we may reduce single-source bias by doing that, the respondents should be general managers or various managers who answer different parts of the questionnaire according to their job scope. In practice, we cannot implement these ideal methods, but regarding organizational-level research, we should note that an individual response cannot be enough. Regarding analysis technique, this study undertook a descriptive comparison and calculated t-statistics to confirm that non-response bias is not a significant issue. However, the low return rate of the survey questionnaire was a potential limitation in the research. Even though the results were consistent with theoretical reasoning, the cross-sectional data were another limitation of this research. Future researchers can use time-series data to improve the shortcoming.

\section{Declaration of Conflicting Interests}

The authors declared no potential conflicts of interest with respect to the research, authorship, and/or publication of this article.

\section{Funding}

The authors received no financial support for the research, authorship, and/or publication of this article.

\section{References}

Al-bdour, A.A., Nasruddin, E., \& Lin, S.K. (2010). The relationship between internal corporate social responsibility and organizational commitment within the banking sector in Jordan. International Journal of Human and Social Sciences, 5(14), 932-951.

Allen, N.J., \& Meyer, J.P. (1990). The measurement and antecedents of affective, continuance and normative commitment to the organization. Journal of occupational psychology, 63(1), 1-18. https://doi.org/10.1111/j.20448325.1990.tb00506.x

Allen, N.J., \& Meyer, J.P. (1996). Affective, continuance, and normative commitment to the organization: An examination of construct validity. Journal of vocational behavior, 49(3), 252-276.

https://doi.org/10.1006/jvbe.1996.0043 
Amabile, T.M. (1988). A model of creativity and innovation in organizations. Research in organizational behavior, 10(1), 123-167.

Amabile, T.M., \& Gryskiewicz, N.D. (1989). The creative environment scales: Work environment inventory. Creativity research journal, 2(4), 231-253. https://doi.org/10.1080/10400418909534321

Amabile, T.M., Conti, R., Coon, H., Lazenby, J., \& Herron, M. (1996). Assessing the work environment for creativity. Academy of management journal, 39(5), 1154-1184. https://doi.org/10.2307/256995

Bettridge, N. (2007). HR \& Corporate Social Responsibility: Using CSR to Enhance Employee Engagement and Deliver HR Objectives. PR Leap. Retrieved February $3^{\text {rd }}, 2012$ from: http://www. prleap. com/pr/87571/

Bharadwaj, S., \& Menon, A. (2000). Making innovation happen in organizations: individual creativity mechanisms, organizational creativity mechanisms or both?. Journal of product innovation management, 17(6), 424-434. https://doi.org/10.1111/1540-5885.1760424

Blasi, A. (1984). Moral identity: Its role in moral functioning. In W.M. Kurtines \& J.L. Gewirtz (Eds.), Morality, moral behavior, and moral development (p. 128-139). New York: John Wiley \& Sons.

Blasi, A. (1995). Moral understanding and the moral personality: The process of moral integration. Moral development: An introduction, 1, 229-253.

Bodla, M.A., \& Naeem, B. (2014). Creativity as mediator for intrinsic motivation and sales performance. Creativity Research Journal, 26(4), 468-473. https://doi.org/10.1080/10400419.2014.961783

Camelo-Ordaz, C., Garcia-Cruz, J., Sousa-Ginel, E., \& Valle-Cabrera, R. (2011). The influence of human resource management on knowledge sharing and innovation in Spain: The mediating role of affective commitment. The international journal of buman resource management, 22(7), 1442-1463.

https://doi.org/10.1080/09585192.2011.561960

Carmeli, A., Gelbard, R., \& Reiter-Palmon, R. (2013). Leadership, Creative Problem-Solving Capacity, and Creative Performance: The Importance of Knowledge Sharing. Human Resource Management, 52(1), 95-121. https://doi.org/10.1002/hrm.21514

Çekmecelioğlu, H.G., \& Günsel, A. (2013). The effects of individual creativity and organizational climate on firm Innovativeness. Procedia-Social and Behavioral Sciences, 99, 257-264. https://doi.org/10.1016/j.sbspro.2013.10.493

Chaudhary, R., \& Akhouri, A. (2018). Linking corporate social responsibility attributions and creativity: Modeling work engagement as a mediator. Journal of cleaner production, 190, 809-821.

https://doi.org/10.1016/j.jclepro.2018.04.187

Chiang, H.H., Han, T.S., \& Chuang, J.S. (2011). The relationship between high-commitment HRM and knowledge-sharing behavior and its mediators. International Journal of Manpower, 32(5/6), 604-622. https://doi.org/10.1108/01437721111158224

Chuang, C.H., Jackson, S.E., \& Jiang, Y. (2016). Can knowledge-intensive teamwork be managed? Examining the roles of HRM systems, leadership, and tacit knowledge. Journal of management, 42(2), 524-554. https://doi.org/10.1177/0149206313478189

Collins, C.J., \& Smith, K.G. (2006). Knowledge exchange and combination: The role of human resource practices in the performance of high-technology firms. Academy of management journal, 49(3), 544-560. https://doi.org/10.5465/amj.2006.21794671

Cooke, F.L., \& He, Q. (2010). Corporate social responsibility and HRM in China: A study of textile and apparel enterprises. Asia Pacific Business Review, 16(3), 355-376. https://doi.org/10.1080/13602380902965558

Cummings, J.N. (2004). Work groups, structural diversity, and knowledge sharing in a global organization. Management science, 50(3), 352-364. https://doi.org/10.1287/mnsc.1030.0134 
de Jesus, S.N., Rus, C.L., Lens, W., \& Imaginário, S. (2013). Intrinsic motivation and creativity related to product: A meta-analysis of the studies published between 1990-2010. Creativity Research Journal, 25(1), 80-84. https://doi.org/10.1080/10400419.2013.752235

De Luque, M.F., \& Sommer, S.M. (2000). The impact of culture on feedback-seeking behavior: An integrated model and propositions. Academy of Management Review, 25(4), 829-849. https://doi.org/10.2307/259209

Ehnert, I., \& Harry, W. (2011). Recent developments and future prospects on sustainable human resource management: introduction to the special issue. Management Revue, 23(3), 221-238. https://doi.org/10.5771/09359915-2012-3-221

European Commission (2001). Promoting a European Framework for Corporate Social Responsibility, Green Paper. European Commission, Directorate-General for Employment and Social Affairs: Luxembourg. Retrieved from: http://ec.europa.eu/education/lifelong-learningpolicy/doc/mobility/com329 en.pdf

Farrukh, M., Sajid, M., Lee, J.W.C., \& Shahzad, I.A. (2019). The perception of corporate social responsibility and employee engagement: Examining the underlying mechanism. Corporate Social Responsibility and Environmental Management, 1-8. https://doi.org/10.1002/csr.1842

Fenwick, T., \& Bierema, L. (2008). Corporate social responsibility: Issues for human resource development professionals. International Journal of Training and Development, 12(1), 24-35. https://doi.org/10.1111/j.14682419.2007.00293.x

Fong, C.Y., Ooi, K.B., Tan, B.I., Lee, V.H., \& Yee-Loong Chong, A. (2011). HRM practices and knowledge sharing: An empirical study. International Journal of Manpower, 32(5/6), 704-723. https://doi.org/10.1108/01437721111158288

Gupta, N., \& Sharma, V. (2016). The relationship between corporate social responsibility and employee engagement and its linkage to organizational performance: A conceptual model. IUP Journal of Organizational Behavior, 15(3), 59.

Hislop, D. (2003). Linking human resource management and knowledge management via commitment: A review and research agenda. Employee relations, 25(2), 182-202. https://doi.org/10.1108/01425450310456479

Hu, L.T., \& Bentler, P.M. (1998). Fit indices in covariance structure modeling: Sensitivity to underparameterized model misspecification. Psychological methods, 3(4), 424. https://doi.org/10.1037/1082-989X.3.4.424

Hu, M.L., Horng, J.S., \& Sun, Y.H. (2009). Hospitality teams: Knowledge sharing and service innovation performance. Tourism Management, 30(1), 41-50. https://doi.org/10.1016/j.tourman.2008.04.009

Hur, W.M., Moon, T.W., \& Ko, S.H. (2018). How employees' perceptions of CSR increase employee creativity: Mediating mechanisms of compassion at work and intrinsic motivation. Journal of Business Ethics, 153(3), 629-644. https://doi.org/10.1007/s10551-016-3321-5

Hwang, A., Francesco, A.M., \& Kessler, E. (2003). The relationship between individualism collectivism, face, and feedback and learning processes in Hong Kong, Singapore, and the United States. Journal of Cross-Cultural Psychology, 34(1), 72-91. https://doi.org/10.1177/0022022102239156

Imran, R., Saeed, T., Anis-Ul-Haq, M., \& Fatima, A. (2010). Organizational climate as a predictor of innovative work behavior. African Journal of Business Management, 4(15), 3337.

Inyang, B.J., Awa, H.O., \& Enuoh, R.O. (2011). CSR-HRM nexus: Defining the role engagement of the human resources professionals. International Journal of Business and Social Science, 2(5), 118-126.

Jafri, M.H. (2010). Organizational commitment and employee's innovative behavior: A study in retail sector. Journal of Management Research, 10(1), 62.

Jamali, D.R., El Dirani, A.M., \& Harwood, I.A. (2015). Exploring human resource management roles in corporate social responsibility: The CSR-HRM co-creation model. Business Ethics: A European Review, 24(2), 125-143. https://doi.org/10.1111/beer.12085 
Jenkins, H. (2009). A 'business opportunity' model of corporate social responsibility for small-and mediumsized enterprises. Business Ethics: A European Review, 18(1), 21-36. https://doi.org/10.1111/j.1467-

8608.2009.01546.x

Kotha, R., Zheng, Y., \& George, G. (2011). Entry into new niches: The effects of firm age and the expansion of technological capabilities on innovative output and impact. Strategic Management Journal, 32(9), 1011-1024. https://doi.org/10.1002/smj.915

Lam, A., \& Lambermont-Ford, J.P. (2010). Knowledge sharing in organisational contexts: A motivation-based perspective. Journal of Knowledge Management, 14(1), 51-66. https://doi.org/10.1108/13673271011015561

Laursen, K., \& Foss, N.J. (2003). New human resource management practices, complementarities and the impact on innovation performance. Cambridge journal of economics, 27(2), 243-263. https://doi.org/10.1093/cje/27.2.243

Lee, C.H., \& Bruvold, N.T. (2003). Creating value for employees: investment in employee development. The International Journal of Human Resource Management, 14(6), 981-1000. https://doi.org/10.1080/0958519032000106173

Lee, L., \& Chen, L.F. (2018). Boosting employee retention through CSR: A configurational analysis. Corporate Social Responsibility and Environmental Management, 25(5), 948-960. https://doi.org/10.1002/csr.1511

Lee, S., Gon Kim, B., \& Kim, H. (2012). An integrated view of knowledge management for performance. Journal of Knowledge management, 16(2), 183-203. https://doi.org/10.1108/13673271211218807

Liu, D., Gong, Y., Zhou, J., \& Huang, J.C. (2017). Human resource systems, employee creativity, and firm innovation: The moderating role of firm ownership. Academy of Management Journal, 60(3), 1164-1188. https://doi.org/10.5465/amj.2015.0230

Magoshi, E., \& Chang. E. (2009). Diversity management and the effects on employees' organizational commitment: Evidence from Japan and Korea. Journal of World Business, 44(1), 31-40. https://doi.org/10.1016/j.jwb.2008.03.018

Maignan, I., \& Ferrell, O.C. (2004). Corporate social responsibility and marketing: An integrative framework. Journal of the Academy of Marketing science, 32(1), 3-19. https://doi.org/10.1177/0092070303258971

McLean, L.D. (2005). Organizational culture's influence on creativity and innovation: A review of the literature and implications for human resource development. Advances in developing buman resources, 7(2), 22 6-246. https://doi.org/10.1177/1523422305274528

Mendibil, K., Hernandez, J., Espinach, X., Garriga, E., \& Macgregor, S. (2007). How can CSR practices lead to successful innovation in SMEs. Publication from the RESPONSE Project, 1-7.

Meyer, J.P., Stanley, D.J., Herscovitch, L., \& Topolnytsky, L. (2002). Affective, continuance, and normative commitment to the organization: A meta-analysis of antecedents, correlates, and consequences. Journal of vocational behavior, 61(1), 20-52. https://doi.org/10.1006/jvbe.2001.1842

Miller, D., \& Lee, J. (2001). The people make the process: commitment to employees, decision making, and performance. Journal of Management, 27(2), 163-189. https://doi.org/10.1177/014920630102700203

Mory, L., Wirtz, B.W., \& Göttel, V. (2016). Factors of internal corporate social responsibility and the effect on organizational commitment. The International Journal of Human Resource Management, 27(13), 1393-1425. https://doi.org/10.1080/09585192.2015.1072103

Murillo, D., \& Lozano, J.M. (2006). SMEs and CSR: An approach to CSR in their own words. Journal of business etbics, 67(3), 227-240. https://doi.org/10.1007/s10551-006-9181-7

Papasolomou-Doukakis, I., Krambia-Kapardis, M. and Katsioloudes, M. (2005). Corporate social responsibility: the way forward? Maybe not! A preliminary study in Cyprus. European business review, 17(3), 263-279. https://doi.org/10.1108/09555340510596661 
Rettab, B., Brik, A.B., \& Mellahi, K. (2009). A study of management perceptions of the impact of corporate social responsibility on organisational performance in emerging economies: The case of Dubai. Journal of Business Ethics, 89(3), 371-390. https://doi.org/10.1007/s10551-008-0005-9

Rogelberg, S.G., \& Stanton, J.M. (2007). Introduction understanding and dealing with organizational survey nonresponse. Organizational Research Methods, 10(2), 195-209. https://doi.org/10.1177/1094428106294693

Sarooghi, H., Libaers, D., \& Burkemper, A. (2015). Examining the relationship between creativity and innovation: A meta-analysis of organizational, cultural, and environmental factors. Journal of business venturing, 30(5), 714-731. https://doi.org/10.1016/j.jbusvent.2014.12.003

Shen, J., Tang, N., \& D'Netto, B. (2014). A multilevel analysis of the effects of HR diversity management on employee knowledge sharing: the case of Chinese employees. The International Journal of Human Resource Management, 25(12), 1720-1738. https://doi.org/10.1080/09585192.2013.859163

Shipton, H., West, M.A., Dawson, J., Birdi, K., \& Patterson, M. (2006). HRM as a predictor of innovation. Human resource management journal, 16(1), 3-27. https://doi.org/10.1111/j.1748-8583.2006.00002.x

Smith, J., \& Gardner, D. (2007). Factors affecting employee use of work-life balance initiatives. New Zealand Journal of Psychology, 36(1), 3.

Spence, L.J., \& Lozano, J.F. (2000). 'Communicating about ethics with small firms: Experiences from the UK and Spain'. In Business Challenging Business Ethics: New Instruments for Coping with Diversity in International Business (pp. 43-53). Springer Netherlands. https://doi.org/10.1007/978-94-011-4311-0_6

Story, J., \& Neves, P. (2015). When corporate social responsibility (CSR) increases performance: exploring the role of intrinsic and extrinsic CSR attribution. Business Ethics: A European Review, 24(2), 111-124. https://doi.org/10.1111/beer.12084

Sundgren, M., Dimenäs, E., Gustafsson, J.E., \& Selart, M. (2005). Drivers of organizational creativity: A path model of creative climate in pharmaceutical R\&D. R\&D Management, 35(4), 359-374. https://doi.org/10.1111/j.1467-9310.2005.00395.x

Tang, Z., Hull, C.E., \& Rothenberg, S. (2012). How corporate social responsibility engagement strategy moderates the CSR-financial performance relationship. Journal of Management Studies, 49(7), 1274-1303. https://doi.org/10.1111/j.1467-6486.2012.01068.x

Thang, N.N., \& Fassin, Y. (2017). The impact of internal corporate social responsibility on organizational commitment: Evidence from Vietnamese service firms. Journal of Asia-Pacific Business, 18(2), 100-116. https://doi.org/10.1080/10599231.2017.1309617

Thurstone, L.L. (1947). Multiple factor analysis. Chicago: University of Chicago Press (p. 535).

Turker, D. (2009). Measuring corporate social responsibility: A scale development study. Journal of business ethics, 85(4), 411-427. https://doi.org/10.1007/s10551-008-9780-6

Van den Hooff, B., \& De Ridder, J.A. (2004). Knowledge sharing in context: the influence of organizational commitment, communication climate and CMC use on knowledge sharing. Journal of knowledge management, 8(6), 117-130. https://doi.org/10.1108/13673270410567675

Von Nordenflycht, A. (2007). Is public ownership bad for professional service firms? Ad agency ownership, performance, and creativity. Academy of Management Journal, 50(2), 429-445.

https://doi.org/10.5465/amj.2007.24634774

Weiss, H.M., \& Cropanzano, R. (1996). Affective events theory: A theoretical discussion of the structure, causes and consequences of affective experiences at work. In B.M. Staw \& L.L. Cummings (Eds.), Research in organization behavior (Vol. 19, p. 1-74). Greenwich, CT: JAI Press.

Welford, R. (2005). Corporate Social Responsibility in Europe, North America and Asia. Journal of Corporate Citizenship, 17, 33-52. https://doi.org/10.9774/GLEAF.4700.2005.sp.00007 
Zhang, X., \& Bartol, K.M. (2010). Linking empowering leadership and employee creativity: The influence of psychological empowerment, intrinsic motivation, and creative process engagement. Academy of management journal, 53(1), 107-128. https://doi.org/10.5465/amj.2010.48037118

Zhang, Y., \& Begley, T.M. (2011). Perceived organisational climate, knowledge transfer and innovation in Chinabased research and development companies. The International Journal of Human Resource Management, 22(1), 34-56. https://doi.org/10.1080/09585192.2011.538967

Intangible Capital, 2019 (www.intangiblecapital.org)

\section{(c) (i) \$}

Article's contents are provided on an Attribution-Non Commercial 4.0 Creative commons International License. Readers are allowed to copy, distribute and communicate article's contents, provided the author's and Intangible Capital's names are included. It must not be used for commercial purposes. To see the complete license contents, please visit https://creativecommons.org/licenses/by-nc/4.0/. 